\title{
Genetic variation of Indian potato (Solanum tuberosum L.) genotypes using chromosomal and RAPD markers
}

\author{
Anath Bandhu Das ${ }^{1 *}$, Iswar Chandra Mohanty ${ }^{1}$, Dawanidhi Mahapatra ${ }^{1}$, Suprava Mohanty ${ }^{2}$ and Ashutosh Ray ${ }^{3}$
}

Received 20 November 2009

Accepted 6 March 2010

\begin{abstract}
Genetic diversity in thirty Indian potatoes were analyzed employing karyotype, genome size and RAPD markers. Chromosome analysis revealed $2 n=4 x=48$ except $c v . K$. Chandramukhi $(2 n=4 x+2=50)$. Total genomic chromosome length and chromosome volume varied from $21.14 \mu \mathrm{m}$ in $\mathrm{cv}$. K. Pukhraj to $31.91 \mu \mathrm{m}$ in $\mathrm{cv}$. MS/89-60 and $14.31 \mu \mathrm{m}^{3} \mathrm{in} \mathrm{cv}$. MS/92-1090 to $33.16 \mathrm{~mm}^{3}$ in $\mathrm{cv} . J W-160$ respectively. $4 \mathrm{C}$ DNA content was significantly varied from $3.640 \mathrm{pg}(\sim 891 \mathrm{Mbp})$ in cv. MS/92-1090 to $11.12 \mathrm{pg}(\sim 2747 \mathrm{Mbp})$ in cv. K. Chandramukhi. RAPD revealed 131 amplified DNA fragments (300 to $2200 \mathrm{bp}$ ) with 79 unique bands (7 to $71 \%$ polymorphism) among the genotypes. Similarity coefficients (ranged from 0.29 to 0.93 ) and cluster analysis reflected the expected trends in relationships of the full and half-sib potato genotypes. Genetic distances obtained from a dendrogram could help breeders to choose the diverse parents for a breeding program aimed at varietal improvement.
\end{abstract}

Key words: 4C DNA content, DNA markers, genotypes, potato, somatic chromosome.

\section{INTRODUCTION}

Potatoes are a high yielding short duration crop that produces high dry matter and protein per unit area and unit time among the major food crops. In terms of quantity, potatoes are the fourth on the list of the crop species after rice, wheat, and corn which are important for human nutrition worldwide. Thus, potatoes have a great potential to meet the increasing food demand world. The nutrient value of potatoes is high and provides carbohydrates, proteins, minerals, vitamin $\mathrm{C}$, a number of B-group vitamins and high quality dietary fibres (Gopalan et al. 1972). Cultivar identification and techniques to assess cultivar homogeneity are important for seed production, germplasm maintenance, crop certification and registration. The new potato cultivars created from the restricted gene pool are likely to be genetically quite similar and hence difficult to differentiate morphologically. Therefore, genetic identification of cultivars and varieties are useful in maintaining a germplasm and planning of breeding programs for new cultivar production to meet the demand of this crop to grow in different agroclimatic environments. Karyotype analysis provides valuable information related to the mechanisms of genome evolution. There are few cytological studies on potatoes because of small and relatively numerous chromosomes (Wilkinson 1994). The somatic chromosome number of $S$. tuberosum reported is $2 n=4 x=48$ (Fish and Karp 1986, Howard 1960, Swaminathan

\footnotetext{
${ }^{1}$ Orissa University of Agriculture and Technology, College of Agriculture, Department of Agricultural Biotechnology, Bhubaneswar, 751003, Orissa, India. *E-mail: a_b_das@hotmail.com

${ }^{2}$ Regional Plant Resource Centre, Cytogenetics Laboratory, Nayapalli, Bhubaneswar, 751015, Orissa, India.

${ }^{2}$ Orissa University of Agriculture and Technology, College of Agriculture, Department of Plant Breeding and Genetics, Bhubaneswar, 751003, Orissa, India.
} 
1954, Swaminathan and Howard 1953, Swaminathan and Magron 1961) with meiotic chromosome analysis (Yeh and Peloquin 1965). Genome size is an important character of fundamental significance that provides useful data in many cytotaxonomic and evolution studies (Price 1976). It plays an important role in tolerance/resistance to low temperatures and in responses to ozone depletion or to the effect of global warming (Bennett and Leitch 1995). DNA markers generated from randomly amplified polymorphic DNA (RAPD) is used to assess and characterize genetic variations among plant genotypes of interest at the DNA level (Williams et al. 1990), which is not necessarily expressed as differences in phenotype. In the present investigation, an attempt has been made to utilize the above mentioned techniques of a genetic variation assessment in 30 genotypes of Solanum tuberosum and subsequently interpret their phylogeny and affinities in the context of an efficient breeding partner selection.

\section{MATERIAL AND METHODS}

Thirty genotypes of Solanum tuberosum L. including cultivars and advanced breeding lines were obtained from the Central Potato Research Institute, Shimla, India through the All India Coordinated Potato Improvement Project, Orissa University of Agriculture and Technology (OUAT), Bhubaneswar (Table 1) and were grown in the experimental green house of OUAT, Bhubaneswar.

\section{Karyotype analysis}

Fresh healthy root tips from the sprouted tubers were pre-treated in a saturated solution of para-dichlorobenzene with aesculine for $3 \mathrm{~h}$ at $18^{\circ} \mathrm{C}$ followed by an overnight fixation in 1:3 acetic acid : alcohol. Chromosomes were stained overnight in 2\% aceto-orcine after cold hydrolysis in $5 \mathrm{~N} \mathrm{HCl}$ for $5 \mathrm{~min}$ and were squashed in $45 \%$ propionic acid. Ten well scattered metaphase plates from each genotype were selected for karyotype analysis. The detail karyotype analysis was performed according to Das and Mallick (1993). The mean values of total genomic chromosome length and total genomic chromosome volume with standard error were calculated.

\section{C nuclear DNA content and genome size}

For the Feulgen cytophotometric estimation of $4 \mathrm{C}$ DNA content, ten fixed root-tips from each genotypes were fixed in 1:3 acetic acid:ethyl alcohol overnight at room temperature, hydrolysed in $1 \mathrm{~N} \mathrm{HCl}$ for $12 \mathrm{~min}$ at $60^{\circ} \mathrm{C}$.
Hydrolysed root tips were washed in distilled water and stained in Schiff's reagent for $2 \mathrm{~h}$ at $14^{\circ} \mathrm{C}$. Each root-tip squash was prepared in $45 \%$ acetic acid. In situ nuclear DNA content was estimated from metaphase chromosomes using a Nikon Optiphot microscope fitted with a microspectrophotometer using monochromatic light at 550 $\mathrm{nm}$ following the Sharma and Sharma method (1980). DNA content was obtained on the basis of optical density, which was converted to picograms (pg) using the $4 \mathrm{C}$ nuclear DNA values (67.1 pg) for Allium cepa var. Deshi (Vant Hof 1963) as a standard. The genome size of different genotypes was calculated from their 4C DNA values and according to their ploidy level. Genome size $=(4 \mathrm{C}$ DNA value / ploidy level) pg $\times 980 \mathrm{Mbp}=$ value in $\mathrm{pg} \times 980$ Mbp. To find out the significant differences in genome size among different species, if any, the analysis of variance (ANOVA) test (Sokal and Rohlf 1973) was performed.

\section{Isolation of DNA}

Genomic DNA was isolated from young expanding leaves using the method of Saghai and Maroof et al. (1984). Leaves $(5 \mathrm{~g})$ were ground to fine powder in liquid nitrogen and suspended in $20 \mathrm{ml}$ of CTAB (Cetryl trimethyl ammonium bromide) buffer containing 2\% CTAB, $100 \mathrm{mM}$ Tris- $\mathrm{HCl}, \mathrm{pH}$ 8, $20 \mathrm{mM}$ EDTA, $1.4 \mathrm{M} \mathrm{NaCl}$, and 1\% bmercaptoethanol. The suspension was incubated at $60^{\circ} \mathrm{C}$ for $1 \mathrm{~h}$ in a water bath. The DNA was extracted in chloroformisoamyl alcohol (49:1) and centrifuged at $5000 \times \mathrm{g}$ for 20 $\min$ at $10^{\circ} \mathrm{C}$. The aqueous phase was transferred to a new sterile $50 \mathrm{ml}$ tube and the DNA was precipitated with a double volume of chilled iso-propanol, and hung out and dried with a vacuum concentrator after rinsing it in $70 \%$ ethanol. Dried DNA was dissolved in a minimum amount of $\mathrm{T}_{10} \mathrm{E}_{1}$ (10 mM Tris-HCl, 1mM EDTA; $\left.\mathrm{pH} 8\right)$. Isolated DNA was further purified by treating with RNAse at $37^{\circ} \mathrm{C}$ for $1 \mathrm{~h}$ followed by chloroform: isoamyl alcohol extraction and ethanol precipitation in the presence of $0.3 \mathrm{M}$ sodium acetate ( $\mathrm{pH}$ 5.2). The DNA was spooled out, washed in $70 \%$ ethanol, air dried and dissolved in a $\mathrm{T}_{10} \mathrm{E}_{1}$ buffer and the DNA concentration was estimated using Versaflour TM Fluorometer (Bio-Rad, USA) using Hoechst 33258 as the fluorimetric dye. The DNA was diluted to a final concentration of $25 \mathrm{ng} \mathrm{mL}^{-1}$ using $\mathrm{T}_{10} \mathrm{E}_{1}$ buffer, to use as a template for RAPD analysis.

\section{PCR amplification and gel electrophoresis}

RAPD profiles were generated by using single decamer random oligonucleotide primers (Operon Technologies, 
Alameda, USA) in polymerase chain reaction (PCR) following the standard protocol of Williams et al. (1990). Each reaction mixture $(25 \mathrm{~mL})$ for PCR amplification was prepared with $25 \mathrm{ng}$ genomic template DNA, $200 \mathrm{mM}$ each of dNTP, $25 \mathrm{ng}$ primer, 0.5 unit Taq DNA Polymerase (Bangalore Genei Pvt. Ltd., Bangalore, India) and 10 ' PCR assay buffer ( $50 \mathrm{mM} \mathrm{KCl,} 10 \mathrm{mM}$ Tris- $\mathrm{HCl}, 1.5 \mathrm{mM} \mathrm{MgCl}_{2}$, $\mathrm{pH}$ 9.0). The PCR reaction was carried out in a Gene Amp PCR 2400 thermal cycler (Perkin Elmer, USA) programmed for 45 cycles using 20 primers each of OP-A, OP-D and PO-N series. The first cycle was programmed for $5 \mathrm{~min}$ at $94^{\circ} \mathrm{C}$ for denaturation, $1 \mathrm{~min}$ at $37^{\circ} \mathrm{C}$ for primer annealing and $2 \mathrm{~min}$ at $72^{\circ} \mathrm{C}$ for DNA polymerisation. In the next 44 cycles the period of denaturation was maintained at $1 \mathrm{~min}$ while the primer annealing and DNA polymerization was the same as in the first cycle. An additional cycle of $15 \mathrm{~min}$ at $72^{\circ} \mathrm{C}$ was used for primer extension. The amplified samples were stored at $4{ }^{\circ} \mathrm{C}$ and separated by electrophoresis in $1.5 \%$ agarose gel in 1 'TAE buffer for $3 \mathrm{~h}$ at $55 \mathrm{~V}$. Gene Ruler 100bp DNA ladder plus (MBI Fermantas, Lithuania) was used as a marker to determine the size of the amplicons. Amplified products were visualized by staining the gel with ethidium bromide and the image was captured in an image analyser Gel Doc-G 700 (Bio-Rad, USA) for documentation and analysis. Only those amplification products that appeared consistently in three replications were scored for further analysis.

\section{RAPD data analysis}

In the RAPD analysis, the presence or absence of the bands was taken into consideration and the difference in the intensity of the band was ignored. Index of diversity was calculated from the frequency of RAPD bands within each genotype. From the RAPD data a binary matrix was obtained. The matrix was elaborated utilizing the multivariate analysis NTSYS-pc (Rohlf 1993). The binary matrix was transformed in a similarity matrix using the Jaccard's coefficient. The cluster analysis was carried out using the UPGMA (Unweighted pair group mean average) method (Sneath and Sokal 1973).

\section{RESULTSAND DISCUSSION}

\section{Chromosome characteristics}

Detailed analysis of somatic chromosomes of 30 genotypes of $S$. tuberosum showed somatic chromosome number $2 \mathrm{n}=4 \mathrm{x}=48$ in all the genotypes except cv. K.
Chandramukhi (K.C.M.) where an aneusomatic set of chromosomes $(2 n=4 x=48+2)$ was found (Figures $1 b-h)$. On the basis of the size of the chromosome and the position of the constrictions, a number of chromosome types were found common with the genotypes studied though they differed from each other in the minute structural details of the karyotype. A general description of the representative types of chromosomes (Figure 1a) is given below:
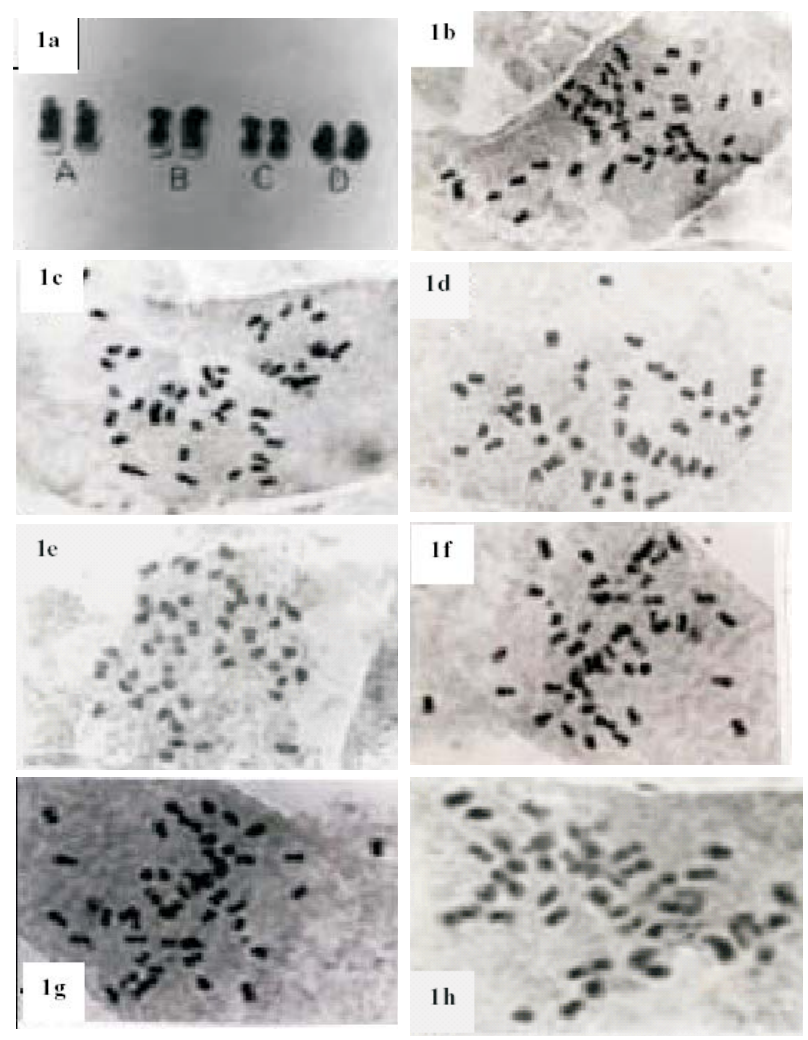

Figure 1. a. Standard types of chromosomes; b-h. Somatic metaphase chromosomes of different potato genotypes $(\times 1942) .1 \mathrm{~b}=\mathrm{K}$. Badshah $2 \mathrm{n}=48,1 \mathrm{c}=K$. Sutlej $(2 \mathrm{n}=48), 1 \mathrm{~d}=\mathrm{K}$. Jawahar $(2 \mathrm{n}=48), 1 \mathrm{e}=J W-$ $160(2 \mathrm{n}=48), 1 \mathrm{f}=$ MTP-I $(2 \mathrm{n}=48), 1 \mathrm{~g}=92$ PT- $27(2 \mathrm{n}=48), 1 \mathrm{~h}=\mathrm{K}$. Chandramukhi $(2 \mathrm{n}=50)$. Magnification 2950X.

Type A - Chromosomes are large to medium sized with two constrictions in nearly median to median and nearly sub median to sub median in position respectively.

Type B - Large to medium sized chromosomes with two constrictions comprised with nearly sub median to sub median positions respectively.

Type C - Chromosomes are medium to small with nearly median to median primary constrictions.

Type D - Chromosomes are medium to small chromosomes with nearly sub median to sub median primary constrictions. 
Detailed analysis of the somatic compliments and the different genomic characteristics showed genotype specific variations in chromosome numbers and structures (Table 1). The karyotype formula of all the genotypes revealed definite differences in the chromosome structure. Type A chromosomes were present in all the genotypes where as Type B were present in 10 genotypes (Table 1). Type $\mathrm{C}$ chromosomes were the most numerous in all the genotypes that varied from 24 in EX/A-680-16 to 40 in K. Jyoti, JW-160 and K. Jawahar. Type D chromosomes varied from 4 to 20 among the studied genotypes; the highest number of Type D chromosomes found in the genotype EX/A-680-16. The type of chromosomes and the number of secondary constricted chromosomes varied significantly with the genotypes. Type A, C and D chromosomes were common in all the genotypes, with high variability in terms of chromosomes in each category. Furthermore, with respect of the karyotype formula, there were no differences between K. Pukhraj and K. Sutlej; DTP-I and DTP-II; JW160 and K. Jawahar; 92PT-27 and MTP-I. In contrast, the genotype chromosome length and volume varied significantly. Karyotype analysis revealed the preponderance of Type $\mathrm{C}$ chromosomes in all the genotypes studied. The total genomic chromosome length varied from $21.14 \mu \mathrm{m}$ in $\mathrm{K}$. Pukhraj to $31.91 \mu \mathrm{m}$ in MS/89-60 and the total genomic chromosome volume varied from $14.31 \mu \mathrm{m}^{3}$ in MS/92-1090 to $33.16 \mu \mathrm{m}^{3}$ in JW-160. The average length of chromosomes varied from $1.76 \mu \mathrm{m}$ in $\mathrm{K}$. Pukhraj to $2.66 \mu \mathrm{m}$ in MS/89-60. The popular cultivar K. Chandramukhi showed comparatively larger chromosomes $(2.49 \mu \mathrm{m})$ than any other released cultivars. Minute observations showed a proportional increase in chromosome length with an increase in chromosome volume. A significant positive correlation ( $r$ $=0.69$ ) was found between the total chromosome length and total chromosome volume suggesting a high interdependence between them at the cultivar level. These facts indicate the predetermined genetic control of chromosome coiling. Evidently, differences in chromosome length or chromosome volume were due to differential condensation and spiralization of the chromosome arms. In addition, the genotype specific compaction of DNA threads along with nucleosomes or the additional gene sequences with altered non-histone proteins in the chromosome played an important role in the chromosomal architecture of the genotypes (Chattopadhyay and Sharma 1990).

Total F\% analysis showed symmetric karyotypes as having median to nearly median chromosomes with a moderate fluctuation of $\mathrm{F} \%$ values from $34.48 \%$ to $48.62 \%$ in MF-I and K. Jyoti respectively. The gradual alterations and shifting of TF\% values might be due to the chromosomal alteration in the genome. The structural alterations in the chromosome morphology as well as variations of secondary constricted chromosomes in the genotypes might be due to the duplication of chromosomes or translocations between the chromosomes with or without secondary constrictions at a very early stage of evaluation (Das 2008).

\section{Diversification in genome size}

The haploid genome size varied significantly from $\sim 890$ bp in MS/92-1090 to 2750 bp in Khupri Chandramukhi (K.C.M.). The aneusomatic cv. K. Chandramukhi had a much larger genome size as compared to others which might be due to the extra pair of chromosomes as well as large chromosome sizes as revealed in the karyotype. The variability in the genome size in different genotypes might be attributed to the loss or addition of many repeats in the genome through alterations in the micro- and macroenvironment during evolution in the selection of new cultivars (Price et al. 1980). The correlation coefficient between total chromosome length and genome size showed significant correlation $(\mathrm{r}=0.521)$. This clearly suggests that the genome size is positively correlated with the total chromosome length. Such variations are in agreement with the findings of other works (Das and Das 1994, Das 2008). The analysis of genome size at the cultivar level in repeated experiments revealed the stable genome size in each genotype. On the other hand the genome size differed significantly among the genotypes. Flavell et al. (1997) reported that differences in genome size depend on the repetitive DNA amount. We agree that variability of genome size can be attributed to the loss or addition of highly repetitive DNA sequences rather than the AT- or GC-rich sequences in a genome (Martel et al. 1997) which reached a certain level and became stabilized during microevolution and gradual selection.

\section{RAPD analysis}

Out of the total 60 primers (OPA, OPD, OPN) used, the 13 most informative ones were selected (Table 2). Figures $2 \mathrm{a}$ and $\mathrm{b}$ depict the RAPD profiles of 30 genotypes amplified by OPA-03 and OPA-05 respectively that showed distinct RAPD profiles of each genotype. Each RAPD marker locus was expressed as two alleles; a presence or absence of the band. The frequency of polymorphic loci was estimated in various potato genotypes considering 
$\mathrm{AB}$ Das et al.

Table 1. Comparative genomic parameters and genome size in 30 genotypes of Solanum tuberosum

\begin{tabular}{|c|c|c|c|c|c|c|c|c|c|}
\hline $\begin{array}{l}\text { Sl. } \\
\text { No. }\end{array}$ & Genotypes & $2 n$ & $\begin{array}{c}\text { Karyotype } \\
\text { formula }\end{array}$ & NSC & $\begin{array}{c}\text { Genomic } \\
\text { chromosome } \\
\text { length } \\
(\mu \mathrm{m} \pm \text { S.E. })\end{array}$ & $\begin{array}{c}\text { Genomic } \\
\text { chromosome } \\
\text { volume } \\
\left(\mu \mathbf{m}^{3} \pm \text { S.E. }\right)\end{array}$ & $\begin{array}{c}\text { Total Form } \\
\%(\text { TF } \%) \\
\text { 土S.E. }\end{array}$ & $\begin{array}{c}\text { 4C DNA } \\
\text { content (p.g.) } \\
\pm \text { S.E. }\end{array}$ & $\begin{array}{c}\text { Haploid } \\
\text { genome size } \\
\text { in Mbp } \\
\text { (1p.g. }=980 \\
\text { Mbp) }\end{array}$ \\
\hline 1 & K.Jyoti & 48 & $4 \mathrm{~A}+40 \mathrm{C}+4 \mathrm{D}$ & 4 & $25.65 \pm 0.11$ & $18.89 \pm 1.28$ & $48.62 \pm 0.03$ & $6.59 \pm 0.023$ & 1615 \\
\hline 2 & K.Pukhraj & 48 & $4 A+36 C+8 D$ & 4 & $21.14 \pm 0.13$ & $14.66 \pm 1.29$ & $42.20 \pm 0.02$ & $4.78 \pm 0.012$ & 1171 \\
\hline 3 & K.Sutlej & 48 & $4 A+36 C+8 D$ & 4 & $24.60 \pm 0.41$ & $19.06 \pm 1.36$ & $42.61 \pm 0.03$ & $7.515 \pm 0.014$ & 1940 \\
\hline 4 & K.Badshah & 48 & $4 \mathrm{~A}+32 \mathrm{C}+12 \mathrm{D}$ & 4 & $26.53 \pm 0.17$ & $20.04 \pm 1.29$ & $38.57 \pm 0.05$ & $5.96 \pm 0.011$ & 1460 \\
\hline 5 & $J W-160$ & 48 & $4 A+40 C+4 D$ & 4 & $26.53 \pm 0.37$ & $33.16 \pm 1.21$ & $45.79 \pm 0.04$ & $5.16 \pm 0.023$ & 1264 \\
\hline 6 & K.Jawahar & 48 & $4 A+40 C+4 D$ & 4 & $23.44 \pm 0.23$ & $15.18 \pm 1.34$ & $44.97 \pm 0.04$ & $5.15 \pm 0.024$ & 1413 \\
\hline 7 & K.Ashoka & 48 & $4 \mathrm{~A}+4 \mathrm{~B}+36 \mathrm{C}+4 \mathrm{D}$ & 8 & $28.04 \pm 0.19$ & $20.42 \pm 1.18$ & $43.32 \pm 0.09$ & $5.60 \pm 0.041$ & 1371 \\
\hline 8 & $J X-90$ & 48 & $4 \mathrm{~A}+4 \mathrm{~B}+32 \mathrm{C}+8 \mathrm{D}$ & 8 & $28.89 \pm 0.21$ & $24.59 \pm 1.21$ & $45.33 \pm 0.07$ & $5.275 \pm 0.011$ & 1293 \\
\hline 9 & JX-576 & 48 & $4 \mathrm{~A}+4 \mathrm{~B}+36 \mathrm{C}+4 \mathrm{D}$ & 8 & $27.40 \pm 0.28$ & $22.68 \pm 1.13$ & $42.37 \pm 0.08$ & $4.37 \pm 0.012$ & 1071 \\
\hline 10 & $85 \mathrm{P}-718$ & 48 & $4 A+32 C+12 D$ & 4 & $25.08 \pm 0.18$ & $20.89 \pm 1.28$ & $36.96 \pm 0.17$ & $7.19 \pm 0.021$ & 1762 \\
\hline 11 & EX/A-680-16 & 48 & $4 A+24 C+20 D$ & 4 & $24.47 \pm 0.15$ & $22.87 \pm 1.17$ & $34.48 \pm 0.06$ & $4.615 \pm 0.023$ & 1131 \\
\hline 12 & $\mathrm{MF}-1$ & 48 & $4 A+28 C+16 D$ & 4 & $23.78 \pm 0.20$ & $19.78 \pm 1.16$ & $44.48 \pm 0.07$ & $4.36 \pm 0.033$ & 1068 \\
\hline 13 & TPS-13 & 48 & $4 \mathrm{~A}+32 \mathrm{C}+12 \mathrm{D}$ & 4 & $24.54 \pm 0.23$ & $22.09 \pm 1.21$ & $45.40 \pm 0.10$ & $6.14 \pm 0.022$ & 1504 \\
\hline 14 & K.C.M. & $48+2$ & $4 \mathrm{~A}+42 \mathrm{C}+4 \mathrm{D}$ & 4 & $29.85 \pm 0.42$ & $27.71 \pm 0.47$ & $45.32 \pm 0.06$ & $11.12 \pm 0.015$ & 2747 \\
\hline 15 & JX-161 & 48 & $4 A+4 B+36 C+4 D$ & 6 & $25.24 \pm 0.34$ & $21.03 \pm 1.33$ & $44.02 \pm 0.07$ & $6.36 \pm 0.016$ & 1558 \\
\hline 16 & $85 \mathrm{P}-670$ & 48 & $4 A+28 C+16 D$ & 4 & $26.73 \pm 0.24$ & $24.21 \pm 1.24$ & $44.73 \pm 0.07$ & $7.645 \pm 0.017$ & 1873 \\
\hline 17 & JTH/C-107 & 48 & $4 \mathrm{~A}+32 \mathrm{C}+12 \mathrm{D}$ & 4 & $24.33 \pm 0.33$ & $24.77 \pm 1.28$ & $42.52 \pm 0.04$ & $7.49 \pm 0.031$ & 1835 \\
\hline 18 & HPS I/13 & 48 & $4 \mathrm{~A}+4 \mathrm{~B}+36 \mathrm{C}+4 \mathrm{D}$ & 8 & $22.29 \pm 0.47$ & $15.12 \pm 1.23$ & $45.33 \pm 0.09$ & $4.71 \pm 0.023$ & 1154 \\
\hline 19 & $92 \mathrm{PT}-27$ & 48 & $4 A+4 B+36 C+4 D$ & 6 & $25.12 \pm 0.22$ & $19.85 \pm 1.26$ & $47.64 \pm 0.05$ & $6.265 \pm 0.024$ & 1535 \\
\hline 20 & MTP-I & 48 & $4 \mathrm{~A}+4 \mathrm{~B}+32 \mathrm{C}+8 \mathrm{D}$ & 6 & $25.81 \pm 0.31$ & $18.61 \pm 1.24$ & $46.26 \pm 0.09$ & $5.42 \pm 0.013$ & 1328 \\
\hline 21 & DTP-I & 48 & $4 A+36 C+8 D$ & 4 & $24.78 \pm 0.24$ & $20.25 \pm 1.53$ & $42.22 \pm 0.03$ & $5.135 \pm 0.024$ & 1258 \\
\hline 22 & DTP-II & 48 & $4 A+36 C+8 D$ & 4 & $21.74 \pm 0.28$ & $17.30 \pm 1.59$ & $43.58 \pm 0.05$ & $4.90 \pm 0.023$ & 1200 \\
\hline 23 & MTP-II & 48 & $4 \mathrm{~A}+4 \mathrm{~B}+36 \mathrm{C}+4 \mathrm{D}$ & 8 & $22.81 \pm 0.38$ & $19.97 \pm 1.38$ & $43.98 \pm 0.08$ & $5.56 \pm 0.025$ & 1362 \\
\hline 24 & MS/92-1090 & 48 & $4 A+36 C+8 D$ & 4 & $21.28 \pm 0.21$ & $14.31 \pm 1.21$ & $44.92 \pm 0.08$ & $3.64 \pm 0.023$ & 891 \\
\hline 25 & MS/89-60 & 48 & $4 \mathrm{~A}+4 \mathrm{~B}+36 \mathrm{C}+4 \mathrm{D}$ & 8 & $31.91 \pm 0.35$ & $29.11 \pm 1.86$ & $42.42 \pm 0.05$ & $6.88 \pm 0.022$ & 1686 \\
\hline 26 & MS/92-2105 & 48 & $4 A+36 C+8 D$ & 4 & $22.29 \pm 0.33$ & $17.02 \pm 1.37$ & $43.51 \pm 0.05$ & $4.295 \pm 0.024$ & 1076 \\
\hline 27 & $\mathrm{JX}-371$ & 48 & $4 \mathrm{~A}+4 \mathrm{~B}+32 \mathrm{C}+8 \mathrm{D}$ & 8 & $26.19 \pm 0.40$ & $23.86 \pm 1.39$ & $41.46 \pm 0.09$ & $5.605 \pm 0.026$ & 1373 \\
\hline 28 & $\mathrm{MS} / 92-3146$ & 48 & $4 A+36 C+8 D$ & 4 & $24.94 \pm 0.38$ & $26.68 \pm 1.28$ & $42.74 \pm 0.06$ & $5.185 \pm 0.012$ & 1270 \\
\hline 29 & MS/92-3128 & 48 & $4 A+36 C+8 D$ & 4 & $24.30 \pm 0.41$ & $27.02 \pm 1.38$ & $44.76 \pm 0.08$ & $5.23 \pm 0.014$ & 1281 \\
\hline 30 & MS/92-209 & 48 & $4 A+36 C+8 D$ & 4 & $27.29 \pm 0.43$ & $23.06 \pm 1.21$ & $42.39 \pm 0.10$ & $4.855 \pm 0.025$ & 1190 \\
\hline
\end{tabular}

NSC: Number of secondary constricted chromosomes; pg: pictogram; Mbp: Mega base pair.

three criteria for primer selection (1) reproducibility (2) number of polymorphic loci per assay and (3) levels of polymorphism detected in a specific group of genotypes. Some of the analyzed potato genotypes had a characteristic RAPD pattern consisting of 6 to 10 major fragments with their size ranging from $300 \mathrm{bp}$ to $2200 \mathrm{bp}$. A total of 113 amplification products were obtained out of which 79 were polymorphic. Similarity index values ranged from 0.29 to 0.93 with a standard deviation of 0.21 indicating a wide genetic base of the potato germplasm used in the analysis. The percentage of polymorphism among the genotypes varied from $7.0 \%$ between K. Sutlej and MTP-I to $71.0 \%$ between JX-90 and $85 \mathrm{P}-670$ respectively. As the polymorphisms were detected as the presence or absence of a particular band, RAPDs scored were dominant markers. Therefore, the genotypes heterozygous or dominant homozygous for a particular locus showed similar bands and thus didn't show polymorphism. Thus, RAPD used here did not detect possible changes in allele frequencies except when the allele detected as the RAPD band was completely lost (Bamberg et al. 2001). Monomorphic bands of the same molecular weight present in all the genotypes 
Table 2. Detailed RAPD analysis in Solanum tuberosum

\begin{tabular}{cccccc}
\hline Primer & $\begin{array}{c}\text { Nucleotide } \\
\text { Sequence (5' }-\mathbf{3}^{\prime} \text { ) }\end{array}$ & $\begin{array}{c}\text { Bands } \\
\text { amplified }\end{array}$ & $\begin{array}{c}\text { Polymorphic } \\
\text { bands }\end{array}$ & $\begin{array}{c}\text { Size range } \\
\text { (bp) }\end{array}$ & $\begin{array}{c}\text { Index of } \\
\text { diversity }\end{array}$ \\
\hline OPA-02 & TGCCGAGCTG & 8 & 6 & $400-2000$ & 2.06 \\
OPA-03 & AGTCAGCCAC & 10 & 8 & $300-2000$ & 3.08 \\
OPA-04 & AATCGGGCTG & 9 & 6 & $500-1900$ & 1.47 \\
OPA-05 & AGGGGTCTTG & 10 & 9 & $400-2200$ & 3.92 \\
OPA-14 & TCTGTGCTGG & 8 & 5 & $500-1800$ & 1.78 \\
OPD-05 & TGAG CGGACA & 8 & 6 & $400-2100$ & 3.21 \\
OPD-06 & ACCTGAACGG & 8 & 5 & $500-1800$ & 1.88 \\
OPD-07 & TTGGCACGGG & 9 & 6 & $400-2000$ & 2.64 \\
OPD-08 & GTGTGCCCCA & 8 & 5 & $700-1900$ & 2.38 \\
OPD-16 & AGGGCGTAAG & 8 & 5 & $400-2000$ & 1.56 \\
OPN-05 & ACTGAACGCC & 9 & 6 & $800-2200$ & 1.92 \\
OPN-06 & GAGACGCACA & 9 & 6 & $400-1500$ & 1.48 \\
OPN-07 & ACCTCAGCTC & 9 & 5 & $300-1900$ & 1.38 \\
\hline & \multicolumn{5}{c}{} \\
\hline
\end{tabular}

The polymorphic band of 1900 bp obtained in the OPA-3 primer was present in all the genotypes except in EX/A-680-16, 85-P670, HSP-1/13, DTP-II, MTP-IIMS/8960, JX-371, MS/92-3146, MS/92-3128 and MS/92-209. A polymorphic band of $1500 \mathrm{bp}$ was present only in JTH/C107 and MS/92-2105. The only unique band of $350 \mathrm{bp}$ was found in MS/92-3146 in the OPA-03 primer whereas, a polymorphic band of $500 \mathrm{bp}$ was found to be common in all the genotypes except DTP-II,MS/92-3128. In POA-05 primers, a monomorphic band of $\sim 700 \mathrm{bp}$ was found to be common in all the genotypes however the dose of this allele noted was quite less in MS/92-3128. Prominent marker
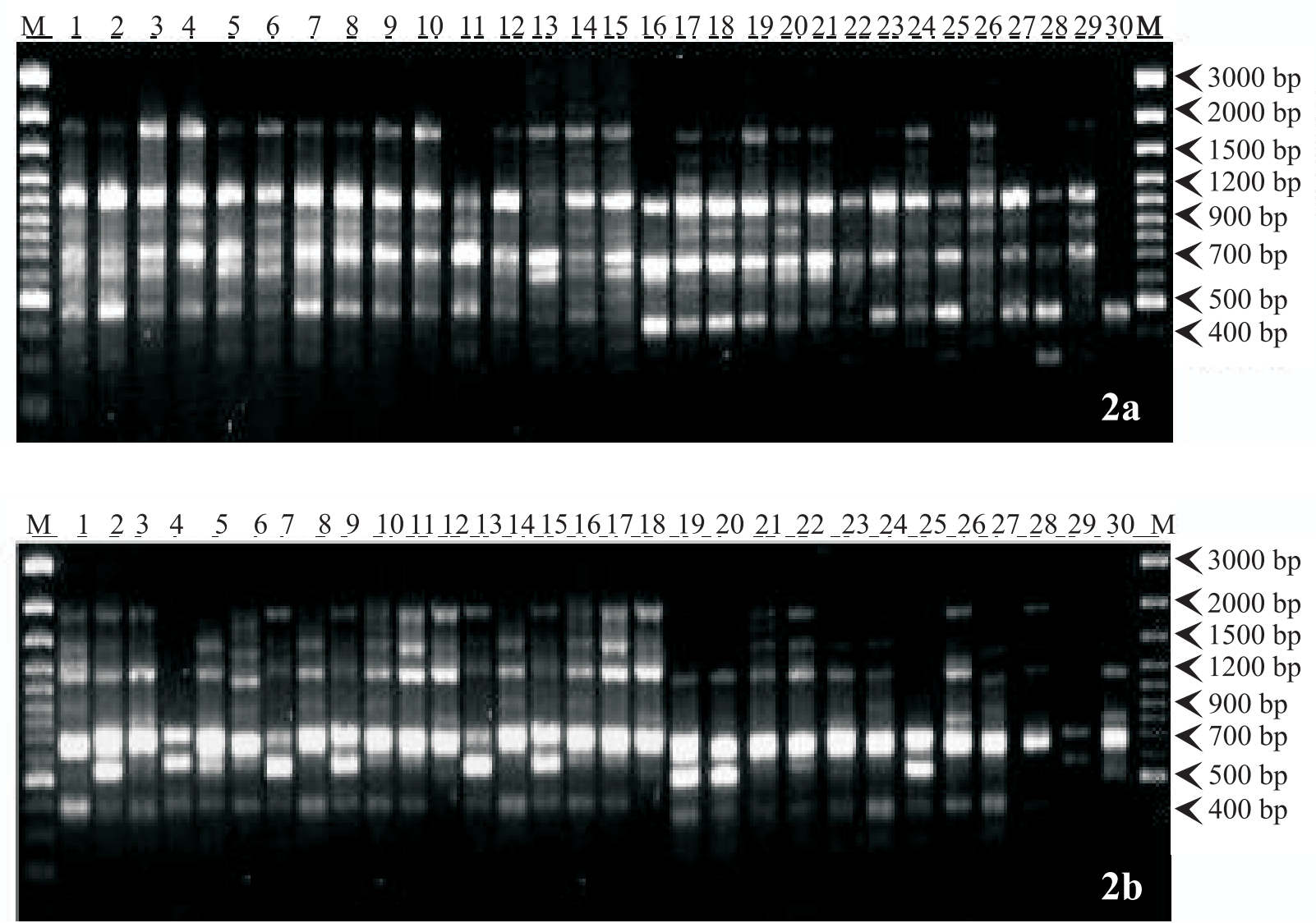

Figures 2a and 2b. RAPD amplification profiles of the 30 potato (Solanum tuberosum) genotypes using primer OPA-03 and OPA-05 respectively with marker DNA (M) Gene Ruler 100 bp DNA ladder plus (MBI Fermentas, Lithuania). The numbers 1-30 indicate 30 potato genotypes as mentioned in Table 1 .

at $1100 \mathrm{bp}$ and at $700 \mathrm{bp}$ amplified with OPA-03 primer; $700 \mathrm{bp}$ and $460 \mathrm{bp}$ bands amplified with OPA-14 primer; 700 bp bands amplified with OPA-05 primer were considered as potato specific markers. bands of $\sim 500$ bp were recorded in K. Pukhraj, K. Badshah, K. Ashoka, JX-576, TPS-13, JX-161, 92PT-27, MTP-I and MS/89-60. The index of diversity among the genotypes varied from 1.38 to 3.92 as observed from the amplified bands with the primers OPN-07 and OPA-05 respectively 


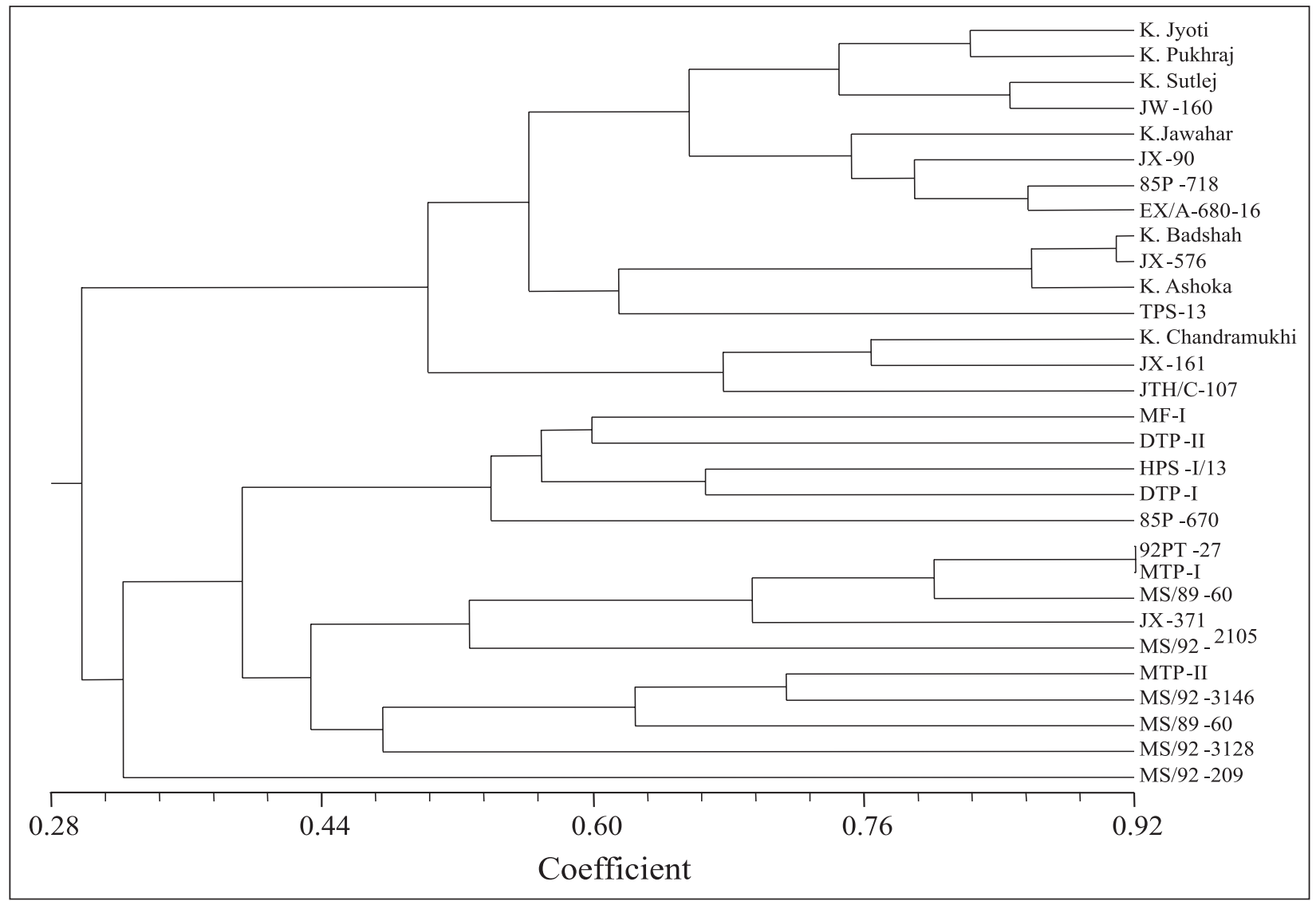

Figure 3. Dendrogram generated from RAPD markers obtained in different primers using the UPGMA algorithm.

(Table 2). All total 11 unique genetic markers were produced in different genotypes of potatoes. The genotype MTP-I produced 2 unique amplified DNA markers of $750 \mathrm{bp}$ in OPD-16 and 2200 bp in OPN-05 primer. A maximum of 3 unique markers were amplified with primer OPA-03 at 300 bp in MS/92-3146; 750 bp in TPS-13; 700 bp in EX/A-68016; OPA-04 and OPD-08 produced 1 and 2 unique markers respectively in K. Ashoka of $1500 \mathrm{bp}$ to $2000 \mathrm{bp}$ fragment size and at $850 \mathrm{bp}$ in 92PT-27. These specific markers obtained by RAPD amplification could be sequenced and specific primers could also be designed to amplify only the band of interest which might be used as cultivar specific markers for cultivar identification. The genetic variability obtained in the Indian potato genotypes are also in accordance with the findings of Genlou et al (2003) in estimating the genetic diversity of 45 deploid potato hybrids and Abbas et al. (2008) in six potato cultivars from Pakistan using RAPD markers. The findings also support the reports on grapes (Lima et al. 2006) and in coffee (Teixeira-Cabral et al. 2004).
The dendrogram obtained on the basis of the genetic distances radically separated the 30 genotypes into two major clusters each having 15 genotypes. First cluster having all comparatively close genetic affinity which were further divided into two sub groups K. Badshah and JX576 found very closely related genotypes. In the second cluster advanced clone 92PT-27 and MTP-I found the closest genetic affinity while advanced breeding line MS/ 92-209 formed out a group with wide genetic variability from the rest of the genotypes. The advanced breeding lines MS/89-60, MS/92-3146, MTP-II remain close to each other and hence treated as clonal duplications while MS/ 92-3128 showed some degree of genetic distance. This cluster analysis could be helpful in plant breeding to make decisions regarding the selection of diverse parents from inter clusters for breeding programs in order to maximize the expression of heterosis for any desired character of agronomic importance.

Crop Breeding and Applied Biotechnology 10: 238-246, 2010 


\section{ACKNOWLEDGEMENTS}

We acknowledge the help of the Director, Central Potato Research Institute, Shimla, India for providing the germplasm used in this investigation. We also thank the Director, Regional Plant Resource Centre, Bhubaneswar for facilitating the laboratory work for this investigation.

\title{
Variação genética entre genótipos de batata (Solanum tuberosum L.) usando cromossomos e marcadores RAPD
}

\begin{abstract}
RESUMO - A diversidade genética entre 30 genótipos indianos de batata foi analisada por meio de cariótipo, tamanho do genoma e marcadores RAPD. Análise cromossômica revelou $2 n=4 x=48$, exceto para a cv. K. Chandramukhi $(2 n=4 x+2=50)$.

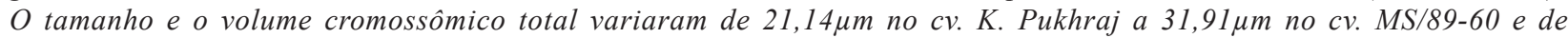
$14,31 \mu \mathrm{m}^{3}$ no $\mathrm{cv}$. MS/92-1090 a 33,16 $\mathrm{m}^{3}$ no $\mathrm{cv}$. JW-160, respectivamente. O conteúdo $4 C$ de DNA variou significativamente de 3,64 pg ( 891 Mbp) no cv. MS/92-1090 a 11,12 pg ( 2747 Mbp) no cv. K. Chandramukhi. Marcadores RAPD revelaram 131 bandas de DNA (300 a 2200 bp) sendo 79 delas exclusivas ( 7 a $71 \%$ de polimorfismo) entre os genótipos. Coeficientes de similaridade (variando de 0,29 a 0,93) e análise de cluster refletiram as tendências esperadas em relação a genótipos meios-irmãos e irmãos completos. Distâncias genéticas contempladas no dendrograma poderão auxiliar melhoristas a escolher parentais diversos para programas de melhoramento visando melhoramento varietal.
\end{abstract}

Palavras-chave: Contéudo 4C de DNA, marcadores de DNA, genótipos, batata, cromossomo somático.

\section{REFERENCES}

Abbas SJ, Rasool G, Shah SRU and Iqbal A (2008) Analysis of genetic diversity in Pakistani potato cultivars by using randomly amplified polymorphic DNA (RAPD) primers. AmericanEurasian Journal of Sustainable Agriculture 2: 50-53.

Bamberg JB, Kiru SD and del Rio AH (2001) RAPD comparison of reputed duplicate populations in the Russion and US potato genebanks. American Journal on Potato Research 78: 365369.

Bennett M and Leitch I (1995) Nuclear DNA Amounts in Angiosperms. Annals of Botany 76: 113-176.

Chattopadhyay D and Sharma AK (1990) Chromosome studies and microspectro-photometric estimation of nuclear DNA in different strains of Coriandum sativum L. Cytobios 64: 4351.

Das AB and Mallick R (1993) Nuclear DNA chromosome changes within the tribe Ammineae. Cytobios 74: 197-207.

Das AB and Das P (1994) Estimation of 4C DNA content and karyotype analysis in edible varieties of banana (Musa acuminata). Cytobios 78: 213-20.

Das AB (2008) Assessment of genetic diversity and phylogenetic analysis of 'Star Cactus' (Astrophytum) through chromosome and RAPD markers. Cytologia 73: 179-188.

Fish N and Karp A (1986) Improvements in regeneration from protoplasts of potato and studies on chromosome stability. Theoretical and Aplied Genetics 72: 405-412.
Flavell RB, Rinpau J and Smith DB (1997) Repeated sequence DNA relationships in four cereal genomes. Chromosome 63: 205-22.

Genlou S, Wang-pruski G, Mayich M and Jong H (2003) RAPD and pedigree-based genetic diversity estimates in cultivated diploid potato hybrids. Theoretical and Applied Genetics 107: 110115.

Gopalan C, Ramashashtri BV and Balsubramanian SC (1972) Nutritive value of Indian Foods. National Institute of Nutrition (Indian Council of Medical Research), Hyderabad, $210 \mathrm{p}$.

Howard HW (1960) Potato cytology and genetics 1952-59. Biblphia Genetics 19: 87-216.

Levan A, Fredyak Sandberg A (1964) Nomenclature for centromeric position on chromosome. Heredita 52: 201-220.

Lima JC, Crippa A, Garrido LR, Camargo UA and Oliveria PRD (2006) Molecular analysis of the seedlessness character in grap using RAPD markers. Crop Breeding and Applied Biotechnology 6: 209-214.

Martel E, Denay D, Siljakyakovtev S, Brown S and Sarr A (1997) Genome size variation and basic chromosome number in pearl millet and fourteen related Pennisetum species. Journal of Heredity 88: 139-43.

Price HJ (1976) Evaluation of DNA content in plants. Botanical Review 42: 27-52. 
$\mathrm{AB}$ Das et al.

Price HJ, Bachman K, Cihambers KL and Riggs J (1980) Detection of intraspecific variation in nuclear DNA content of Microseris douglasii. Botanical Gazette 141: 195-198.

Rohlf FJ (1993) Ntsys-PC. Numerical taxonomy and multivariate analysis system, version 1.80. Exeter Software, NY, 887p.

Saghai-Maroof MA, Sliman KM, Jorgens RA and Allard RW (1984) Ribosomal DNA spacer-length polymorphisms in barley: Mendelian inheritance, chromosomal location, and population dynamics. Proceedings of the National Academy of Science of the United States of America 81: 8014-8018.

Sneath PHA and Sokal R (1973) Numerical taxonomy. Freeman, San Francisco, 573p.

Sharma AK and Sharma A (1980) Chromosome techniques: theory and practice. $3^{\text {rd }}$ ed., Butteruorths, London, 724p.

Sokal PR and Rohlf FJ (1973) Introduction to Biostatistics. Freeman, San Francisco, 368p.

Swaminathan MS and Howard HW (1953) The cytology and genetics of the potato (Solanum tuberosum) and related species. Biblphia Genetics 16: 1-192.

Swaminathan MS (1954) Nature of polyploidy in some 48 chromosome species of the genus Solanum section Tuberarium. Genetics 39: 59-76.
Swaminathan MS and Magron ML (1961) Origin and cytogenetics of the commercial potato. Advances in genetics 10: 217 256.

Teixeira-Cabral TA, Sakiyama NS, Zambolim L, Pereirs AA, Barros EG and Silva DG (2004) Characterization of differential coffee tree hosts for Hemileia vastatrix Berk. Et Br. with RAPD markers. Crop Breeding and Applied Biotechnology 4: $68-73$.

Van't Hof J and Sparrow AH (1963) A relationship between DNA content, nuclear volume, and minimum mitotic cycle time. Proceedings of the National Academy of Science of the United States of America 49: 897-902.

Wilkinson MJ (1994) Genome evolution in potatoes. In: J. E. Bradshaw and G. R. Mackay (eds) Potato genetics. University Press, UK, p. 43-70.

Williams JGK, Kubelik AR, Livak KJ, Rafalski JA and Tingey SV (1990) DNA polymorphisms amplified by arbitrary primers are useful as genetic markers. Nucleic Acids Research 18: 65316535 .

Yeh BP and Peloquin SJ (1965) Pachytene chromosomes of the potato (Solanum tuberosum subsp. Andigena). American Journal of Botany 52: 1014-1020. 